\title{
Comparative study of oxytocin bolus and oxytocin infusion during caesarean section
}

\author{
Teena C. Bannihatti, Hema K. R., Pradeep N. M.*
}

Department of Obstetrics and Gynecology, Sri Siddhartha Medical College, Karnataka, India

Received: 22 November 2021

Revised: 15 December 2021

Accepted: 16 December 2021

*Correspondence:

Dr. Pradeep N. M.,

E-mail: pradeepnm.nm@gmail.com

Copyright: (C) the author(s), publisher and licensee Medip Academy. This is an open-access article distributed under the terms of the Creative Commons Attribution Non-Commercial License, which permits unrestricted non-commercial use, distribution, and reproduction in any medium, provided the original work is properly cited.

\begin{abstract}
Background: The incidence of postpartum haemorrhage varies from 2-11\%. Postpartum haemorrhage complicates approximately $4 \%$ of deliveries in most large obstetric services. Postpartum haemorrhage is the third major cause of maternal mortality next to pregnancy induce hypertension (pre-eclampsia) and infection. Prevention, early recognition and prompt appropriate intervention are keys to minimizing its impact. Conventionally loss of more than $500 \mathrm{ml}$ of blood following vaginal delivery and $1000 \mathrm{ml}$ of blood following caesarean section is defined as postpartum haemorrhage. In this study we compared the efficacy of intravenous oxytocin bolus (2 IU) dose followed by infusion (160 mIU/minute) and only i.v. oxytocin infusion following delivery of fetus in elective and emergency LSCS with regard to uterine tone.

Methods: This study was a prospective observational study. 200 low risk patients scheduled to undergo elective and emergency caesarean section under spinal anaesthesia in Department of obstetrics and gynecology, SSMC, Tumkur. Group A included i.v. bolus + i.v. injection, group B: i.v. infusion.

Results: There was significant drop in haemoglobin and PCV in both group A and group B. But it was comparable among two groups. At $15^{\text {th }}$ minute $\mathrm{MBP}$ was $77.2 \mathrm{~mm}$ of $\mathrm{Hg}$ and $80.04 \mathrm{~mm}$ of $\mathrm{Hg}$ in Group B. In group A better uterine tone was achieved earlier compared to group B at 2, 5, 10, 20 minutes.

Conclusions: It was concluded from this study that oxytocin i.v. bolus with infusion causes earlier attainment of better uterine tone when compared with only infusion.
\end{abstract}

Keywords: Caesarean section, I.V. bolus, Oxytocin, Postpartum haemorrhage, Uterine tone

\section{INTRODUCTION}

Postpartum hemorrhage (PPH) is one of the most common causes of maternal death throughout the world. Pregnancy and childbirth involves significant health risks, even to women with no preexisting health problem. Worldwide there are an estimated 500,000-600,000 deaths of mothers in childbirth annually of which $25 \%$ are due to severe bleeding. World Health Organization (WHO) also estimated 20 million annual maternal morbidities due to hemorrhage. ${ }^{1}$ In developing countries, where maternal mortality rates are exponentially higher, PPH plays an even greater role.
Where maternal mortality is high and resources are limited, the introduction of low cost evidence based practices to prevent and manage postpartum hemorrhage can improve maternal and infant survival.

The WHO technical working group (1990) defined postpartum haemorrhage as bleeding from genital tract in excess of $500 \mathrm{ml}$ in the first 24 hours after delivery. ${ }^{2}$ The incidence of PPH is estimated to be $10 \%$ of all deliveries, $2-4 \%$ after vaginal delivery and $6 \%$ after caesarian section with uterine atony being the cause in $50 \%$ of cases. ${ }^{3}$

Uterine atony, which complicates 1 in 20 deliveries, results in excessive blood loss when adequate myometrial 
contraction fails to occur after placental expulsion. As such the normal physiological mechanism of uterine contraction and retraction of uterus is disturbed in LSCS due to incision on uterus. In cases of elective LSCS, since labour has not started, the endogenous oxytocin is absent and sensitivity of uterus to oxytocin exogenously administered is less. Risk factors for uterine atony include conditions where the uterus is overdistended (polyhydramnios, multiple gestation, fetal macrosomia, fatigued, rapid or prolonged labour, chorioamnionitis), or simply inability to contract (use of uterine relaxing agents like tocolytics or general anesthesia). ${ }^{1}$

Active management of third stage of labour, including early cord clamping and controlled cord traction and administration of oxytocic drugs such as ergometrine and oxytocin have been beneficial. ${ }^{4}$ Prophylactic routine use of oxytocics has been shown to reduce incidence of PPH by up to $40 \% .^{5}$

The best management of the third stage would be one that effectively minimizes serious problems such as blood loss and retained placenta, while interfering as little as possible with the physiological mechanisms of placental delivery and bonding between mother and baby, and has few side effects. ${ }^{6}$

Recent studies show that there are still wide variations in practice around the world in the management of third stage of labour. Methyl ergometrine is a conventional oxytocic used extensively but is associated with unpleasant side effects like hypertension. ${ }^{7}$ Intravenous oxytocin used alone has been found effective in preventing postpartum hemorrhage and results in fewer side effects. Due to the short half-life, oxytocin is normally administered as an infusion, ideally in a fluid medium which is isotonic with plasma (Ringer lactate, normal saline) so that the risk of water toxicity is minimized. Doses used range from 5 to 10 units per hour, with 250 to $500 \mathrm{ml}$ fluid as vehicle, per hour. Poor and delayed increases in uterine tones led to trials of bolus doses (over 5 to 10 seconds) to overcome these problems and at the same time, to avoid deleterious hemodynamic disturbances. ${ }^{8}$

The present study was an attempt to compare the efficacy of intravenous oxytocin bolus (2 IU) dose followed by infusion (160 mIU/minute) and only intravenous oxytocin infusion (160 mIU/minute) following delivery of fetus in elective and emergency LSCS with regard to their influence on- uterine tone, blood loss by difference in hemoglobin and hematocrit, need for additional oxytocics and side effects of the drugs.

\section{METHODS}

It was a prospective observational study conducted at Sri Siddhartha Medical College and research centre, Tumkur, Karnataka, India. The study took place for a period of 1 year from October 2020 to September 2021.

\section{Inclusion criteria}

Inclusion criteria for study was all low-risk patients scheduled to undergo elective and emergency lower segment caesarean section.

\section{Exclusion criteria}

Exclusion criteria included complicated cases with increased risk of atony or excessive bleeding like known placenta previa, multiple gestation, more than 2 previous LSCS, grandmultipara and history of repeated abortions, cardiovascular instability, systemic illnesses, prolonged labour with failed induction, fetal distress, contraindications to spinal anesthesia and patient refusal.

The aim was to compare the efficacy of intravenous oxytocin bolus dose followed by infusion and only intravenous oxytocin infusion after fetal extraction in elective and emergency LSCS (equivalent to management of third stage of labour, but here in LSCS).

The study was conducted in 200 low risk patients scheduled to undergo elective and emergency lower segment caesarean section under spinal anesthesia, in the Department of Obstetrics and Gynaecology, SSMC, Tumkur. They were divided into two groups of 100 each by random sampling technique.

\section{Group A}

Patients were given 2 IU ( $2 \mathrm{ml}$ ) of Intravenous oxytocin bolus followed by oxytocin infusion $160 \mathrm{mIU} /$ minute following delivery of fetus in LSCS.

\section{Group B}

Intravenous oxytocin infusion $160 \mathrm{mIU} /$ minute following delivery of fetus in LSCS.

An informed and written consent was taken from the patients who met the inclusion criteria. These women underwent a thorough general and systemic examination including cardiovascular system, respiratory system, per abdomen and per vaginal examinations.

Primary parameters studied were the uterine tone and the effects on haemodynamics.

Intra operatively grades of uterine tone was assessed at $2^{\text {nd }}$, $5^{\text {th }} 10^{\text {th }}, 20^{\text {th }}, 30^{\text {th }}, 45^{\text {th }}, 60^{\text {th }}$ minute after oxytocin administration. Uterine tone was assessed by 4 point scale by palpation and rugosities on uterus $1=$ atonic, $2=$ inadequately contracted, $3=$ adequately contracted, $4=$ well contracted.

Alterations in mean arterial pressure (MAP) and heart rate (HR) were noted at 3, 6, 9, 15, 20, 25, 30, 40, 50, 60 minutes. 
Packed cell volume (PCV)/hematocrit and hemoglobin ( $\mathrm{Hb}$ in $\mathrm{gm} \%$ ) values were obtained at the time of admission to the labour room and repeated 24 hours after the last oxytocin infusion by Wintrobes method and Sahlis hemoglobinometer respectively.

Need for augmenting uterine tone by increasing the rate of oxytocin infusion by $25 \%$, further by $50 \%$ increase in infusion rate, methyl ergometrine, carboprost if any, noted.

Adverse effects, if any, including nausea, vomiting, headache, diarrhea/bronchospasm/flushing are noted.

Statistical analysis was done using chi square test and students ' $t$ ' test.

\section{RESULTS}

This study was conducted in 200 low risk pregnant women posted for emergency and elective Lower segment cesarean section (LSCS). Both A and B groups were similar with regard to antepartum variables i.e., maternal age, gravidity, parity and gestational age.

Table 1: Age wise distribution of study subjects.

\begin{tabular}{|llll|}
\hline Age group & $\begin{array}{l}\text { Groups } \\
\text { Group A } \\
(\boldsymbol{\%})\end{array}$ & $\begin{array}{l}\text { Group B } \\
(\boldsymbol{\%})\end{array}$ & Total $(\%)$ \\
\hline $\mathbf{1 8 - 2 1}$ years & $30(30)$ & $22(22)$ & $52(26.0)$ \\
\hline $\mathbf{2 2 - 2 5}$ years & $56(56)$ & $59(59)$ & $115(57.5)$ \\
\hline $\mathbf{2 6 - 2 9}$ years & $12(12)$ & $14(14)$ & $26(13.0)$ \\
\hline$\geq 30$ years & $02(02)$ & $05(05)$ & $07(03.5)$ \\
\hline Total & $100(100)$ & $100(100)$ & $200(100)$ \\
\hline
\end{tabular}

chi square- 2.75 , df- 3 , p value- 0.43 (not significant)

The age distribution is shown in Table 1. Majority of patients were between 22-25 years of age in both the groups. Mean age of patients in group A was 22.89 \pm 2.6 years and in group B was $23.76 \pm 3.2$ years. There was no difference in the age distribution between 2 groups statistically.

Table 2: Comparison of $\mathrm{Hb}$ and PCV before and after LSCS between group A and group $B$.

\begin{tabular}{|lll|l|}
\hline Parameters & $\begin{array}{l}\text { Group } \\
\text { Group A } \\
(\text { mean } \pm \text { SD) }\end{array}$ & $\begin{array}{l}\text { Group B } \\
(\text { mean } \pm \text { SD) }\end{array}$ & P value* \\
\hline Hb (gm\%) & & & \\
\hline Before LSCS & $10.26 \pm 1.0$ & $10.42 \pm 1.1$ & 0.36 \\
\hline After LSCS & $9.72 \pm 0.9$ & $9.52 \pm 1.0$ & 0.15 \\
\hline PCV & & & \\
\hline Before LSCS & $31.06 \pm 3.1$ & $31.50 \pm 3.2$ & 0.33 \\
\hline After LSCS & $28.51 \pm 3.2$ & $28.46 \pm 3.0$ & 0.91 \\
\hline
\end{tabular}

In group $\mathrm{A}$, there was decrease in haemoglobin concentration by $0.54 \pm 0.1 \mathrm{gm} \%$. In group $\mathrm{B}$, there was decrease in haemoglobin concentration by $0.90 \pm 1 \mathrm{gm} \%$. It was not statistically significant.

In group $\mathrm{A}$, there was decrease in $\mathrm{PCV}$ of $1.55 \pm 3.1$, in group B, there was decrease in PCV of $3.04 \pm 3.1$. It was not statistically significant.

There were fall in hemoglobin and PCV in both the groups.

Estimated blood loss in group A was $491 \mathrm{ml}$ and in group B was $587 \mathrm{ml}$

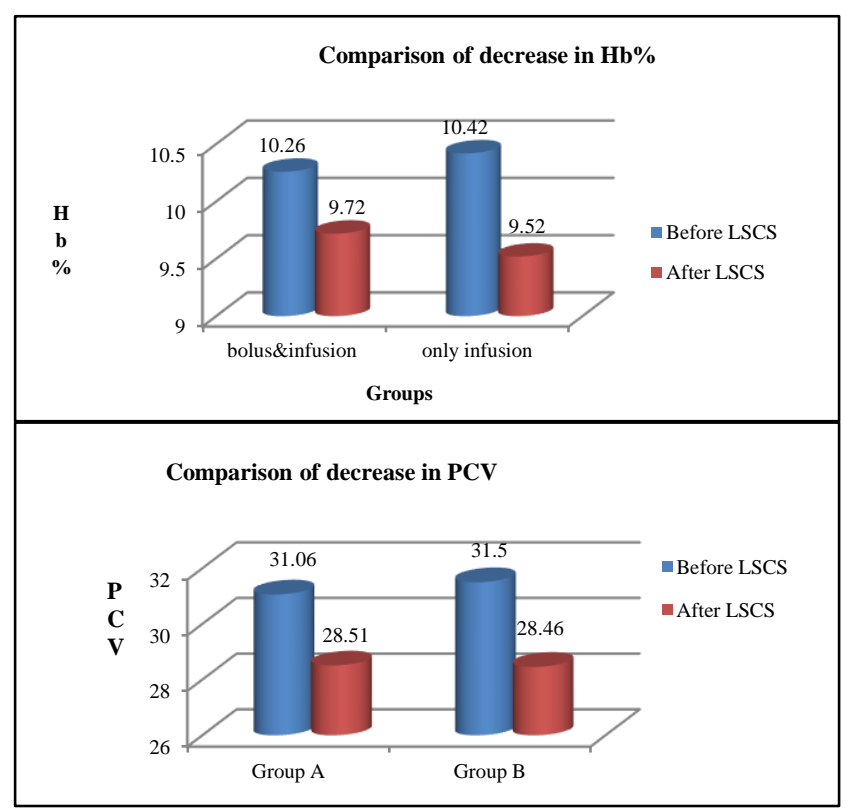

Figure 1: Comparison of decrease in $\mathrm{Hb} \%$ and $\mathrm{PCV}$.

Table 3: Comparison of uterine tone at 2 minutes between group $\mathrm{A}$ and group $\mathrm{B}$.

\begin{tabular}{|llll|}
\hline Uterine tone & $\begin{array}{l}\text { Group A } \\
\mathbf{N}(\%)\end{array}$ & $\begin{array}{l}\text { Group B } \\
\mathbf{N}(\%)\end{array}$ & $\begin{array}{l}\text { Total } \\
\mathbf{N}(\%)\end{array}$ \\
\hline Atonic & $00(00)$ & $04(04)$ & $04(02)$ \\
\hline $\begin{array}{l}\text { Inadequate } \\
\text { contracted }\end{array}$ & $16(16)$ & $44(44)$ & $60(30)$ \\
\hline $\begin{array}{l}\text { Adequately } \\
\text { contracted }\end{array}$ & $78(78)$ & $52(52)$ & $130(65)$ \\
\hline $\begin{array}{l}\text { Well } \\
\text { contracted }\end{array}$ & $06(06)$ & $00(00)$ & $06(03)$ \\
\hline Total & $100(100)$ & $100(100)$ & $200(100)$ \\
\hline
\end{tabular}

Chi square- 28.38 , df- 3 , p value- 0.003 (significant)

At 2 minutes, in group $\mathrm{A}$, in $78 \%$ of cases, uterus was adequately contracted, followed by $16 \%$ with inadequately contracted uterus. In $6 \%$ of cases uterus was well contracted. None had atonic uterus.

In group B, $52 \%$ of cases had adequately contracted uterus, followed by $44 \%$ inadequately contracted. In $4 \%$ uterus was atonic. None had well contracted uterus. 
The difference between this uterine tonicity at 2 minutes between 2 groups was statistically significant.

Table 4: Comparison of uterine tone at 5 minutes between group $\mathbf{A}$ and group $B$.

\begin{tabular}{|llll|}
\hline Uterine tone & $\begin{array}{l}\text { Group A } \\
\mathbf{N}(\%)\end{array}$ & $\begin{array}{l}\text { Group B } \\
\mathbf{N}(\%)\end{array}$ & $\begin{array}{l}\text { Total } \\
\mathbf{N}(\%)\end{array}$ \\
\hline Atonic & $00(00)$ & $01(01)$ & $01(00.5)$ \\
\hline $\begin{array}{l}\text { Inadequate } \\
\text { contracted }\end{array}$ & $01(01)$ & $25(25)$ & $26(13.0)$ \\
\hline $\begin{array}{l}\text { Adequately } \\
\text { contracted }\end{array}$ & $17(17)$ & $38(38)$ & $55(27.5)$ \\
\hline $\begin{array}{l}\text { Well } \\
\text { contracted }\end{array}$ & $82(82)$ & $36(36)$ & $118(59.0)$ \\
\hline Total & $100(100)$ & $100(100)$ & $200(100)$ \\
\hline
\end{tabular}

Chi square- 49.10, df- 3, p value- 0.01 (significant)

By 5 minutes, in group A, uterus was well contracted in $82 \%$ of cases, adequately contracted in $17 \%$. In $1 \%$ uterus was inadequately contracted. None had atonic uterus. That is in $99 \%$ of patients uterus was adequate to well contracted.

In group $\mathrm{B}$, in $38 \%$ of cases, uterus was adequately contracted, followed by $36 \%$ well contracted. In $25 \%$ uterus was inadequately contracted. Only $1 \%$ had atonic uterus.

The difference between this uterine tonicity at 5 minutes between 2 groups was statistically significant.

Table 5: Comparison of uterine tone at $\mathbf{1 0}$ minutes between group $\mathbf{A}$ and group $B$.

\begin{tabular}{|llll|}
\hline Uterine tone & $\begin{array}{l}\text { Group A } \\
\mathbf{N}(\%)\end{array}$ & $\begin{array}{l}\text { Group B } \\
\mathbf{N}(\%)\end{array}$ & $\begin{array}{l}\text { Total } \\
\mathbf{N}(\%)\end{array}$ \\
\hline Atonic & $00(00)$ & $00(00)$ & $00(00)$ \\
\hline $\begin{array}{l}\text { Inadequate } \\
\text { contracted }\end{array}$ & $00(00)$ & $02(02)$ & $02(01.0)$ \\
\hline $\begin{array}{l}\text { Adequately } \\
\text { contracted }\end{array}$ & $07(07)$ & $34(34)$ & $41(20.5)$ \\
\hline $\begin{array}{l}\text { Well } \\
\text { contracted }\end{array}$ & $93(93)$ & $64(64)$ & $157(78.5)$ \\
\hline Total & $100(100)$ & $100(100)$ & $200(100)$ \\
\hline
\end{tabular}

Chi square- 25.13, df- 3, p value- 0.001 (significant)

At 10 minutes, in group A, in $93 \%$ of cases, uterus was well contracted, followed by $7 \%$ adequately contracted. None had inadequately contracted and atonic uterus.

At 10 minutes, in group B, in $64 \%$ of cases, uterus was well contracted, followed by $34 \%$ adequately contracted. In $2 \%$ uterus was inadequately contracted. None had atonic uterus.

There were improvements in uterine tone by $10^{\text {th }}$ minute in both groups as compared to $5^{\text {th }}$ minute. All patients in group A had adequate to well contracted uterus.
By $20^{\text {th }}$ minute, both the groups had adequate to well contracted uterine tones.

Table 6: Comparison of uterine tone at $\mathbf{2 0}$ minutes between group $\mathbf{A}$ and group $\mathbf{B}$.

\begin{tabular}{|llll|}
\hline Uterine tone & $\begin{array}{l}\text { Group A } \\
\mathbf{N}(\%)\end{array}$ & $\begin{array}{l}\text { Group B } \\
\mathbf{N}(\%)\end{array}$ & $\begin{array}{l}\text { Total } \\
\mathbf{N}(\%)\end{array}$ \\
\hline Atonic & $00(00)$ & $00(00)$ & $00(00)$ \\
\hline $\begin{array}{l}\text { Inadequate } \\
\text { contracted }\end{array}$ & $00(00)$ & $00(00)$ & $00(00)$ \\
\hline $\begin{array}{l}\text { Adequately } \\
\text { contracted }\end{array}$ & $00(00)$ & $05(05)$ & $05(02.5)$ \\
\hline $\begin{array}{l}\text { Well } \\
\text { contracted }\end{array}$ & $100(100)$ & $95(95)$ & $195(97.5)$ \\
\hline Total & $100(100)$ & $100(100)$ & $200(100)$ \\
\hline
\end{tabular}

Chi square- 5.12, df- 2, p value- 0.03 (significant)

\section{Uterine tone at different intervals in group $A$ and $B$.}

In group A, better uterine tonicity was obtained earlier as we can see from the graph. At $2^{\text {nd }}$ minute, $84 \%$ of patients had adequately contracted uterus. By $5^{\text {th }}$ minute, $99 \%$ of patients had satisfactory contraction $(82 \%$ well contracted and $17 \%$ adequately contracted). By $10^{\text {th }}$ minute, even better quality of contraction could be obtained.

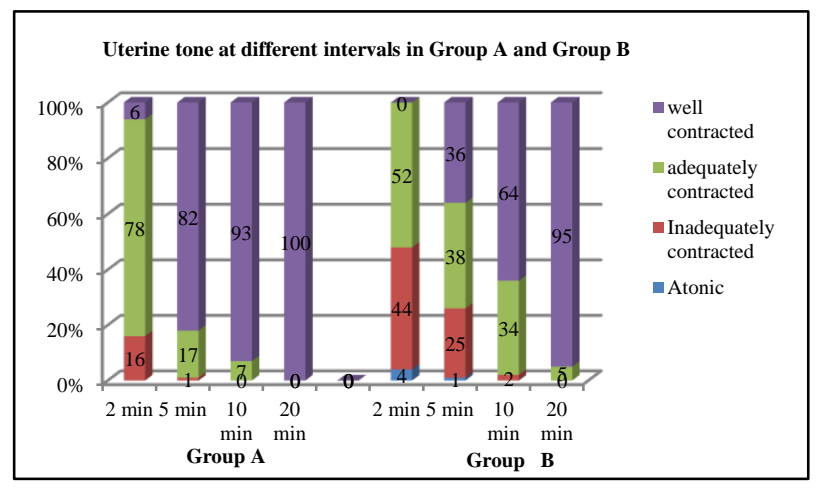

Figure 2: Uterine tone noted at different intervals in group $\mathbf{A}$ and group $\mathbf{B}$.

Table 7: Need for additional uterotonics.

\begin{tabular}{|llll|}
\hline $\begin{array}{l}\text { Extra } \\
\text { uterotonics }\end{array}$ & $\begin{array}{l}\text { Group A } \\
\mathbf{N}(\%)\end{array}$ & $\begin{array}{l}\text { Group B } \\
\mathbf{N}(\%)\end{array}$ & $\begin{array}{l}\text { Total } \\
\mathbf{N}(\%)\end{array}$ \\
\hline $\begin{array}{l}\text { No increase in } \\
\text { infusion rate }\end{array}$ & $97(97)$ & $68(68)$ & $165(82.5)$ \\
\hline $\begin{array}{l}\mathbf{2 5 \%} \text { increase } \\
\text { in infusion rate }\end{array}$ & $03(03)$ & $28(28)$ & $31(15.5)$ \\
\hline $\begin{array}{l}\mathbf{5 0 \%} \text { increase } \\
\text { in infusion rate }\end{array}$ & 00 & $04(04)$ & $04(02.0)$ \\
\hline $\begin{array}{l}\text { Methyl } \\
\text { ergometrin }\end{array}$ & 00 & 00 & 00 \\
\hline Carboprost & 00 & 00 & 00 \\
\hline Total & $100(100)$ & $100(100)$ & $200(100)$ \\
\hline
\end{tabular}

Chi square- 29.08, df- 4, p value- 0.001 (significant) 
In Group B, there was gradual increase in tone. At 2 minutes $44 \%$ had inadequately contracted uterus, which came down to $25 \%$ at $5^{\text {th }}$ minute. And adequate contraction was established by 10 th minute in $98 \%$ of patients.

In group $\mathrm{A}$, in $97 \%$ of patients good uterine tone was achieved and there was no need of any other extra uterotonic, only $3 \%$ needed augmentation of tone by increase in rate of infusion by $25 \%$.

In group B, 32\% needed augmentation of tone by increase in oxytocin infusion rate.

There was no need for methyl ergometrine and carboprost in both groups.

\section{DISCUSSION}

\section{Changes in $\mathrm{Hb}$ and PCV before and after LSCS between Group A and Group B}

Blood loss during LSCS was expected to be $800-1000 \mathrm{ml}$. In an RCT conducted at Liverpool, UK regarding intraoperative blood loss during LSCS, the mean measured blood loss was $487 \mathrm{ml}$. Oxytocin causes acquisition of good uterine tone, hence less blood loss. Estimated blood loss could be measured by visual estimation, drop in haemoglobin, drop in PCV or radioisotope labelled RBCs. In our study we compare the blood loss between two groups by drop in haemoglobin and drop in PCV.

In group $\mathrm{A}$, there was decrease in haemoglobin concentration by $0.54 \mathrm{gm} \%$ from baseline values. There was decrease in PCV of 1.55 (Table 5). Similarly there was fall in hemoglobin by $0.9 \mathrm{gm} \%$ and PCV by 3.04 in group B (Table 6). Estimated blood loss in bolus group was $491 \pm 49 \mathrm{ml}$, and in only infusion group was $587 \pm 59 \mathrm{ml}$. Estimated blood loss was less in bolus group.

In study conducted by Thomas et al, where 30 women were allocated to receive $5 \mathrm{u}$ oxytocin bolus or as infusion over 5 minute, where there was no differences in estimated blood loss between bolus and infusion groups. ${ }^{9}$

In a study conducted by Gregory et al, 99 women received an intravenous oxytocin bolus (10 IU push) and 102 women received an infusion (10 IU in $500 \mathrm{ml}$ saline at 125 $\mathrm{ml} /$ hour) at delivery of the anterior shoulder. ${ }^{10}$ Estimated blood loss was calculated from drop in hemoglobin similar to our study. The dilute oxytocin infusion group experienced a greater mean estimated blood loss $(423.7 \mathrm{ml}$ compared with $358.1 \mathrm{ml}, \mathrm{P} \pm 0.029$, t test), and a greater drop in hemoglobin (admission minus postpartum) (17.4gm/1 compared with $11.4 \mathrm{gm} / 1, \mathrm{P} \pm 0.002$, t test) compared with the oxytocin bolus group.

\section{Comparison of uterine tone}

Oxytocin causes contraction of the uterine smooth muscle fibres and acts as living ligatures at the site of placental implantation. Acquisition of uterine tone is measured by four point scale. In group A, better uterine tonicity is acquired earlier. At $2^{\text {nd }}$ minute, $84 \%$ of patients had adequately contracted uterus. By $5^{\text {th }}$ minute, $99 \%$ of patients had satisfactory contraction $(82 \%$ well contracted and $17 \%$ adequately contracted). By $10^{\text {th }}$ minute, even better quality of contraction could be obtained.

In group $\mathrm{B}$, there was gradual increase in tone. At 2 minutes $44 \%$ had inadequately contracted uterus, which came down to $25 \%$ at $5^{\text {th }}$ minute. And adequate contraction was established by $10^{\text {th }}$ minute in $98 \%$ of patients.

So oxytocin bolus can be given in cases where atonic PPH is expected like, multifetal gestation, polyhydromnios, big baby, prolonged labour, obstructed labour.

\section{Need for extra uterotonics}

In case if satisfactory uterine tone not acquired extra uterotonics were given at surgeons request. First step was to increase the infusion rate by $25 \%$ and then by $50 \%$. If uterus still not responding, methyl ergometrine and carboprost were given. In group A, in $97 \%$ of patients good uterine tone was achieved and there was no need of any other extra uterotonic, only in $3 \%$ of patients $25 \%$ increase in infusion rate was needed to attain good uterine tone. However in group B, $68 \%$ required no increase in infusion, $28 \%$ required $25 \%$ increase in infusion rate, $4 \%$ required $50 \%$ increase in infusion rate. So, group B experienced increased use of additional oxytocics (32.3\% compared with $3 \%$ ) compared with group A. There was no need for methergine and carboprost in both groups. The need for extra uterotonics between 2 groups was statistically significant (Table 7).

In a study conducted by Gregory et al, the dilute oxytocin infusion group experienced increased use of additional oxytocics (35.3\% compared with $22.2 \%, \mathrm{P} \pm 0.044$, Fisher exact test) compared with the oxytocin bolus group. ${ }^{10}$

Limitations of our study are mainly being small sample size due to which the adverse effect of administration of intravenous bolus oxytocin cannot be studied adequately.

\section{CONCLUSION}

It was concluded from this study that oxytocin i.v. bolus with infusion causes earlier attainment of better uterine tone when compared with only infusion and there was a need for more uterotonics when only oxytocin infusion was given.

\section{ACKNOWLEDGMENTS}

The authors would like to thank Department of Obstetrics and Gynecology, Sri Siddhartha Medical College Tumkur and the pregnant women who volunteered to participate in this study. 
Funding: No funding sources

Conflict of interest: None declared

Ethical approval: The study was approved by the Institutional Ethics Committee Sri Siddhartha Academy of higher Education, Tumkur

\section{REFERENCES}

1. Dildy GA. Postpartum hemorrhage new management option. Clin Obstet Gynecol. 2002;45(2):330-44.

2. World Health Organization. The prevention and management of post partum haemorrhage. Report of a technical working group. WHO: Geneva; 3-6 July, 1989, WHO / MCH / 90.7, World Health Organization; 1990.

3. Amy JJ. Severe postpartum haemorrhage: A rational approach. Nat Med J India. 1998;11:86-8.

4. WHO 2001. Global estimates of maternal mortality for 1995: Results of an in-depth review analysis and estimation strategy. Geneva: WHO; 2001.

5. Prendiville W, Elbourne D, Chalmers I. The effects of routine oxytocic administration in the management of the third stage of labour: an overview of the evidence from controlled trials $\mathrm{Br} \mathrm{J}$ Obstet Gynaecol. 1988;95:3-16.
6. Mudaliar AL. Causation and stages of labour. Clinical Obstetrics. 9th edn. Madras Orient Longman; 1994:85-96.

7. Cunningham FG, Lenovo KJ, Bloom SL, Dashe JS, Hoffman BL, Casey BM, et al, eds. Parturition. In: Williams Obstetrics. 20th edn. USA: Appleton and Lange; 1997:261-317.

8. Misra R, ed. Postpartum haemorrhage. In: Ian Donald's Practical Obstetric Problems, 5th edn. New Delhi: B.1. Publications; 1998:748-794.

9. Thomas JS, Koh SH, Cooper GM. Haemodynamic effects of oxytocin given as i.v. bolus or infusion on women undergoing caesarean section. Br J Anaesth. 2007;98:116-9.

10. Davies GA, Tessier JL, Woodman MC, Lipson A, Hahn PM. Maternal hemodynamics after oxytocin bolus compared with infusion in the third stage of labor: a randomized controlled trial. Obstet Gynecol. 2005;105(2):294-9.

Cite this article as: Bannihatti TC, Hema KR, Pradeep NM. Comparative study of oxytocin bolus and oxytocin infusion during caesarean section. Int $\mathbf{J}$ Reprod Contracept Obstet Gynecol 2022;11:211-6. 